\section{Olympic row over sex testing}

SIR - Your News item about sex testing at the Olympics (Nature 353, 784; 1991) raises an important issue that has caused serious concern among medical geneticists, endocrinologists and others for more than 20 years. The problem stems from the decision taken by the International Olympic Committee (IOC) in 1967 to use sex chromatin testing as a criterion of eligibility for women competitors. The purpose was to exclude males and people with intersex conditions, who might have an unfair advantage in muscle mass, from competing in women's events. Its use since 1968 has helped to reduce innuendo and scandal in the mass media about individual competitors who were thought to have a 'masculine' body habitus.

But there is no evidence that its use has led to the detection of males masquerading in female events. On the contrary, and as predicted by medical geneticists, a substantial number of women athletes have been unfairly debarred from competing. Although the IOC has not responded to requests for information it holds on the number of athletes found on testing to be incligible, it is believed that at least 1 in 500 female athletes have had to withdraw from competition on this account (M. A. Ferguson-Smith, \& E. A. Ferris, $B r . J$. Sports Med. 25, 17-21; 1991). As your article correctly states, the majority of women affected are "XY females" with the androgen insensitivity syndrome who clearly have no athletic advantage over normal XX women.

It is not hard to imagine the distress and humiliation felt by an athlete confronted with failure to pass a sex test. A graphic account of the trials of one courageous athlete who found herself in this position can be found in the March 1991 issue of Women's Sports \& Fitness. In brief, the athlete passed the test in 1983, forgot her eligibility certificate in 1985 and failed the test when it was repeated. There followed a harrowing period during which she was publicly debarred from competition, lost her scholarship and had her achievements struck from the record books. Finally her persistence was rewarded and she was reinstated in 1988. There are many cases where an athlete confronted with a similar experience has preferred to withdraw rather than submit to further humiliation.

The time is long since past for these inappropriate sex tests to be abandoned. However, the IOC seem unconcerned and proposes to introduce a polymerase chain reaction test for $Y$-specific DNA for all female competitors at the forthcoming Olympic Games in Albertville and Barcelona. The Council of the International Amateur Athletic Federation has a more sympathetic approach. It wishes to see genetic sex tests dropped and has recently made a quite different proposal. It believes that there are good medical reasons for all athletes, men and women, to have a health check before competing to exclude physical disorders that might put the athlete at risk (for example, Marfan's syndrome among basketball players). Although not primarily designed for gender verification, such an examination would obviously not allow a male to masquerade as a female. The health check would be organized in the athlete's own country by sports physicians accredited by the National Olympic Committee. Random checks for gender verification would not be required at international events, as the procedures used for the collection of urine samples during control of anabolic steroids and other drugs would readily identify males. These arrangements should provide sufficient assurance to the IOC and those women athletes who require it that all competitors are eligible. To persist with genetic sex tests would simply continue the present discrimination against women athletes.

M. A. FERGUSON-SMith (Department of Pathology, University of Cambridge, Cambridge, UK), AlISON CARLSON (Amberst Drive, Hasting-onHudson, New York, USA), ALBERT DE LA CHAPELLE (Department of Medical Genetics, University of Helsinki, Finland), ANKE EHRHARDT (Department of Psychiatry, Columbia University, New York, USA), ELIZABETH FERRIS (Brown Candover, near Airesford, Hants, UK), ARNE LUUNGQVIST (Department of Pathology, Karolinska Institute Stockholm, Sweden), MYRON GENEL (Yale University School of Medicine, New Haven, Connecticut, USA), JOE LEIGH SIMPSON (University of Tennessee College of Medicine, Memphis, Tennessee USA)

\section{Future fuels}

SIR - Hall et al. ${ }^{1}$, in their Commentary article on the greenhouse advantages of using solar energy via biofuels, seem to have overlooked some realities. First, barring a vast catastrophe, the human population will reach or exceed 10,000 million by the next century. Second, there is a global food crisis. It is clear that nutrition is not simply calories, and the Sadik report ${ }^{2}$ shows the scale of the problem, with endemic anaemia in Egypt, India, Indonesia and Pakistan, and so on. Food per capita is declining in about half the world, even in biofuelled Brazil. Third, global soil erosion is reaching crisis proportions $\mathrm{s}^{3,4}$ and reliable water resources are a problem in many regions.

Yes, there are lands such as United States, Canada and parts of Europe that could move to massive use of biofuels. They all have the necessary conditions of a land-food surplus. But such countries are also the emergency bread-baskets of the world, and who would hold the surplus if they diverted possible resources to biofuels?

Climate is not steady-state on many timescales. In 1988, the United States had a corn deficit. What would happen to food and fuel if we had a year without summer, perhaps driven by a really large volcanic event ${ }^{5}$ ? We have not had such an event this century.

At present, we spend very large sums of money and expend much energy on the development of nuclear fusion energy. But we have access to a very nice fusion reactor in the Sun, which delivers about $2 \mathrm{cal} \mathrm{cm}^{-2} \mathrm{~min}^{-1}$. Surely this must be the sustainable energy source for the future, with the great deserts used as energy farms, and every rooftop and wind source used on local and regional scales? Solar energy systems, combined with rational population reduction, could lead to a planet of diversity and opportunity.

Department of Geology,

University of Western Ontario.

London, Canada N6A 5B7

\footnotetext{
1. Hall, D. O., Mynick. H. E. \& Williams. R. H. Nature 353 11-12 (1991).

Sadik, N. State of World Population 1989 (UNFPA 1989).

Brown. L. R. State of the World 1991 (Norton, 1991).

. Fyfe, W. S. Episodes 12, 249-254 (1989).

5. Grove, J. M. The Little ice Age (Methuen, 1988)
}

\section{Infant food}

SIR - As Nigerians, we suggest that the answer to the issue of advertising campaigns for formula feeding in developing countries lies somewhere between the view expressed by Jenny Daniel (Nature $353,496 ; 1991)$ and that of the author of your leading article (Nature 352, 266; 1991). Manufacturers of formula feeds have in recent years been responsive to criticisms by the World Health Organisation (WHO) and other international bodies, but clearly there is room for improvement. It would seem best to us, however, that international agencies and governments as well as manufacturers of formula feeds should spend more effort on emphasizing the virtues of breastfeeding, thus enabling those of us in developing countries to make both a free and informed choice based on the facts.

A. O. ADEBAIO

University of Ibadan,

A. F. ADEBAJO

Nigeria 